\title{
Государственная поддержка грудному вскармливанию как способ достижения Целей в области устойчивого развития Ганиева Г.С. ${ }^{1}$, Агаев А.А. ${ }^{1}$
}

\author{
${ }^{1}$ Азербайджанский Медицинский Университет
}

Для корреспонденции: Ганиева Г.С., Азербайджанский Медицинский Университет, Баку, Азербайджанская Республика, email: gala17_2000@yahoo.com

Абстракт. Кормление грудью вносит ключевой вклад в выживание, здоровье и благополучие детей раннего возраста и здоровье матерей. Проще говоря, оно дает детям наилучший возможный старт в жизни. В течение первых двух лет жизни дети очень уязвимы. Но, даже самые уязвимые из них (например, маловесные) растут и развиваются нормально, если первые полгода они находятся на исключительно грудном вскармливании (ГВ). ГВ снижает риск развития в последующие годы таких заболеваний, как атеросклероз, гипертоническая болезнь, сахарный диабет, ожирение1 и др.

Ключевые слова: грудное вскармливание, цели в области устойчивого развития, грудное молоко

Введение. Грудное молоко содержит иммунологические факторы, которые защищают от воздействия антигенов и реакции на них, в т.ч. защищает от развития аллергии на коровье молоко. Отсутствие грудного вскармливания является фактором риска синдрома внезапной смерти внешне здорового ребенка ${ }^{2}$. У детей, получавших грудное молоко, выше коэффициент интеллектуального развития и познавательные способности ${ }^{3}$.

Если же слишком рано вводится другая пища или напитки, или если они не даются безопасными способами, в правильных количествах и в оптимальные сроки, темпы физического развития резко замедляются, что может привести к задержке роста. К моменту достижения такими детьми двухлетнего возраста многие из них останавливаются в своем физическом развитии. И главное, этот процесс необратим, будучи взрослыми, они останутся малорослыми и у них, скорее всего, будут понижены умственные и физические способности. С другой стороны, несоответствующая практика питания может привести и к детскому ожирению, которое является растущей проблемой здравоохранения во многих странах.

Иными словами ГВ имеет решающее значение для достижения многих Целей в области устойчивого развития (ЦУР) до 2030 г, к которым присоединился Азербайджан. Оно улучшает питание (ЦУР2), предотвращает детскую смертность и снижает риск неинфекционных заболеваний (ЦУР3), а также поддерживает когнитивное развитие и образование (ЦУР4). Более того, грудное молоко - это способ питания влияющий и на здоровье планеты. Почему? Потому что - это естественное, возобновляемое питание, которое "производится и доставляется потребителю" без загрязнения, упаковки и отходов.

Как же обстоит дело с частотой и продолжительностью грудного вскармливания в республике? Последнее МДИ (2011г.), свидетельствует о том, что около $85 \%$ детей в возрасте 0-6 месяцев, 55\% - в возрасте 6-12 месяцев и почти $28 \%$ - в возрасте 12-24 месяцев получают ГВ, но лишь $9 \%$ детей в возрасте до 6 месяцев находятся на исключительном ГВ. Исследования свидетельствуют также о раннем введении прикорма, так в дополнение в грудному молоку - 10\% детей получают другой вид молока, 22\% - воду, 19,4\% - другие жидкости и 24,5\% детей в возрасте до 6 месяцев уже получают дополнительное питание твердую или пюреобразную пищу. 
Распространенным, к сожалению, остается вскармливание из бутылочки: 2/3 младенцев в возрасте до 2 месяцев вскармливаются из детской бутылки с соской, а к возрасту 4-5 месяцев - $86,2 \%{ }^{4}$.

Низкая частота и продолжительность грудного вскармливания, перевод детей на искусственное вскармливание, ранний и неадекватный прикорм вполне могут быть причиной проблем с пищевым статусом у детей до 5 лет. Так, по результатам МедикоДемографического Исследования (МДИ, 2011г.) показатель хронического нарушения питания или т.н. низкорослость среди детей до 5 лет, составляет - 16,4\%, и максимально выражен в возрастной группе 2-4 года, достигая к 4 годам почти 22\% (т.е. практически у каждого пятого ребенка). ${ }^{4}$ Распространенность анемии (2013) составляет 24\% и максимальна (40\%) - в возрастной группе 6-11 месяцев. А уровень железодефицитных состояний наиболее проявлен в группе 12-24 месяца и составляет $27 \%$ и др.

\section{Заключение}

Правительство, лица, принимающие решения, партнеры в области развития, научные круги, средства массовой информации, активистыобщественники и другие должны объединить усилия для стимулирования и поддержки грудного вскармливания в интересах более устойчивого будущего.

Для этого, в первую очередь должна быть разработана национальная программа по оптимизации питания детей до 5 лет, включающая:

a. внедрение, поощрение грудного вскармливания и консультирование по его вопросам в работу родовспомогательных служб и детских лечебнопрофилактических учреждений, b. разработку рекомендаций по оптимизации питания беременных и кормящих женщин, включая использование адресной помощи;

c. разработку рекомендаций по срокам введения, ассортимента продуктов и блюд прикорма,

d. совершенствование методов профилактики и диетотерапии алиментарно-зависимых заболеваний, пищевой аллергии и др.

Все это будет способствовать снижению расходов на здравоохранение.

Финансовый источник: При написании статьи не использовались финансовые ресурсы.

Конфликт интересов: Нет.

\section{СПИСОК ЛИТЕРАТУРЫ}

1. Long-term effects of breastfeeding A SYSTEMATIC REVIEW Bernardo L. Horta, Cesar G. Victora 2013)

2. Ford R.P.K. et al. breastfeeding and the risk of sudden infant death syndrome. International Journal of Epidemiology, 22, 885-890, 1993

3. Anderson J.W. et al. Breastfeeding and cognitive development: a meta- analysis. American journal of clinical nutrition,70, 525535,1999

4. Demography and Health Survey Azerbaijan, 2011, Final Report, Baku, 2013

5. Azərbaycan üzrə Milli Qidalanma Sorğusu (AzMQS), 2013-cü il, BMT-nin Ușaq fondu (UNICEF), Azərbaycan Respublikası Səhiyyə Nazirliyi, Amerika Birləşmiş Ştatların Beynəlxalq İnkişaf Agentliyi (USAİD) və Dünya Bankı (WB). 